DOI 10.22363/2312-9220-2021-26-1-71-78

UDC 821.222.1

\title{
The Construction of Insider - Outsider in Anglophone Writings from Northeast India
}

\author{
Debajyoti Biswas, Rupanjit Das ${ }^{\varpi}$ \\ Bodoland University, \\ P.O. - Rangalikhata, Kokrajhar(BTAD), Assam, 783370, Republic of India \\ $\square$ dasrupanjit@gmail.com
}

\begin{abstract}
The works of three writers from northeast India, Temsula Ao's These Hills Called Home, Mamang Dai's Stupid Cupid and Anjum Hasan's Lunatic in my Head that cover the problem of identity in relation to the insider - outsider politics in the region are examined. The northeast India is in many ways a miniature India because it houses people from various ethnicity and linguistic groups. However, much of the immigration took place after the East India Company annexed the northeast region starting from 1826. The extraction of the resources and subjugation of the people in this region by the colonisers and later by successive Indian governments has left an indelible mark of cultural imperialism triggering social haemorrhage. This changing position of the insider - outsider is not only a part of the political discourse but also the literature that is produced in this region. The analysis of the writings of Temsula Ao, Mamang Dai, and Anjum Hasan allows to look at the problem from two perspectives: the indigenous population experiencing anxiety and leading various violent campaigns to expel so-called outsiders, and the northeasterners facing similar racial prejudices when visiting mainland India and being subjected to derogatory racial slurs.
\end{abstract}

Keywords: Northeast India, nationalism, subnationalism, Anjum Hasan, Mamang Dai, Temsula Ao

Conflicts of interest. The authors declare that there is no conflict of interest.

Article history: submitted December 12, 2020; revised December 29, 2020; accepted January 9, 2021.

For citation: Biswas, D., \& Das, R. (2021). The construction of insider - outsider in anglophone writings from Northeast India. RUDN Journal of Studies in Literature and Journalism, 26(1), 71-78. http://dx.doi.org/10.22363/2312-9220-2021-26-1-71-78 


\title{
«Свой» и «чужой» в произведениях писателей северо-востока Индии
}

\author{
Д. Бисвас, Р. Дас \\ Бодоландский университет, \\ Республика Индия, 783370, Кокраджххар, Acсам, n/я - Rangalikhata \\ $\checkmark$ dasrupanjit@gmail.com
}

\begin{abstract}
Аннотация. Исследуются работы трех писателей из Северо-Восточной Индии: «Эти холмы, называемые домом» Темсулы Ао, «Глупый амур» Маманг Дай и «Сумасшедший в моей голове» Анджум Хасан, посвященные вопросу идентичности в связи с действующей в регионе политикой инсайдеров и аутсайдеров. Северо-Восточная Индия во многих отношениях является Индией в миниатюре, потому что здесь проживают люди различных этнических и языковых групп. Однако большая часть иммиграции произошла после того, как Ост-Индская компания аннексировала северо-восточный регион, начиная с 1826 года. Добыча ресурсов и подчинение людей колонизаторами, а затем сменяющими друг друга правительствами Индии оставили неизгладимый след культурного империализма, вызывая социальное кровотечение. Эта меняющаяся позиция «своего» - «чужого» нашла отражение не только в политическом дискурсе, но и в литературе региона. Анализ произведений Темсулы Ао, Маманг Дай и Анджум Хасан позволяет взглянуть на проблему с двух позиций: коренного населения, испытывающего беспокойство и ведущего различные насильственные кампании, чтобы изгнать так называемых чужаков, и северо-восточных жителей, сталкивающихся с аналогичными расовыми предрассудками, посещая материковую Индию, и подвергающихся уничижительными расовыми оскорблениями.
\end{abstract}

Ключевые слова: Северо-Восточная Индия, национализм, субнационализм, Анджум Хасан, Маманг Дай, Темсула Ао

Заявление о конфликте интересов. Авторы заявляют об отсутствии конфликта интересов.

История статьи: поступила в редакцию 12 декабря 2020 г.; принята к публикации 9 января 2021 г.

Для цитирования: Biswas D., Das R. The construction of insider - outsider in anglophone writings from Northeast India // Вестник Российского университета дружбы народов. Серия: Литературоведение. Журналистика. 2021. Т. 26. № 1. С. 71-78. http://dx.doi.org/ 10.22363/2312-9220-2021-26-1-71-78

\section{Introduction}

In Post 1947 India, when the idea of nationalism came to be wielded as an imposition of cultural homogeneity, it naturally met with the dissention of the masses because it directly confronted with the aspiration of the people inhabiting in the northeast region of India $[1 ; 2$. P. 6; 3]. The Northeast India is a cartographic construct which existed as a frontier area in the official discourse of the Bri- 
tish administration and later in Indian administration [4; 5]. The region is also the house of tribal people, mostly of mongoloid origin. However, with the nationalisation of space, the region was strategically peopled at regular intervals since 1826 , thereby saturating the tribal population with the non-tribal [6; 7]. This created resentment among the indigenous population who felt that not only the outsiders overwhelm their numbers but also the valuable resources are extracted by the government of India [8; 9]. Consequently, a sense of protest and resistance gave rise to the feeling of sub-nationalism in the entire northeast India over a period of time. This sub-nationalism emerged by drawing its impetus from the local culture, myth and sense of an alternate history of the people and eventually it became deeply jingoistic in nature something similar to the 'extremist style of politics' as pointed out by Partha Chatterjee while explaining the problems of Nationalism in Asian context [10. P. 9]. This sub-nationalism is not only a resistance to pan-Indian nationalism but it also excludes the participation of the people who have migrated to this region in different phases [11]. It is with this background that the northeast region becomes a fertile ground for ethnic conflicts, communal clashes and secessionist demands by rebel groups $[1 ; 12 ; 13]$. These conflicts give rise to the politics of insider/outsider binary that is used as the yardstick in determining privileges [14]. The prevailing socio-political scenario, therefore, clearly brings into question the involvement of at least three agencies: the tribal who are claiming their rights, the state, and the immigrants. As such these conflicts and issues find expression in the literature produced in this region. Whereas, there has been no political solution to the problems hitherto, the intelligentsia who have experienced the shockwaves of these problems tend to voice it in their fictional works which automatically become a discourse that bridges the lacuna created by the lack of representation and political rejection, as Temsula Ao writes in These Hills Called Home, "I have endeavoured to revisit the lives of people whose pain has so far gone unmentioned and unacknowledged" [15. P. 9]. This paper proposes to examine the how the position of insider/outsider changes and influences identity formation as one can see in the literary works produced in this region. The three texts, Temsula Ao's These Hills Called Home, Mamang Dai's Stupid Cupid and Anjum Hasan's Lunatic in My Head, chosen for this study informs the reader of this conflict pertaining to identity and belongingness.

\section{The dynamics of insider - outsider}

Temsula Ao's These Hills Called Home: Stories from a War Zone, is a collection of ten short stories which recount the countless ordeal faced by the Nagas during their secessionist struggle to free their land from Indian union. The title of the short story collection too justifies the aspirations of these people. These hills are the homes of the Naga people, which have shaped their culture, their identity, and their history and they are so intricately entwined that they cannot be separated from each (people and place). The intrusion of outsiders into this region was passively resisted for some time when it was under the British administration, and those times were termed as 'old days'; however in the present day, the Naga people cannot stand to bear the presence of 'outsiders' in these areas and such presence is only considered as trespassing. The British allotted the Assamese, Bengali, 
Bihari, Marwari and Nepali settlers the lands, which were never theirs, and so this tradition if continued would make the Nagas outsiders in their own homeland. Although Temsula Ao does not explicitly mention the cause of this turmoil in the late nineteen fifties, it becomes evident during the course of the narrative. Further, the narrator not only justifies the rebellion of the Nagas but also gives it a hue of romanticism:

"These young people were caught, as it were, at the crossroads of Naga history. The wave of dissidence and open rebellion was heady wine for many of them and they abandoned family, school careers and even permanent jobs to join the band of nationalists to liberate the homeland from forces, which they believed were inimical to their aspirations to be counted among the free nations of the world" [15. P. 10].

Whereas, on the one hand the rebels (undergrounds) are projected as nationalists who have taken the onus of liberating the nation from the Indian government; the Indian administration, on the other hand, seems to be given a colonial makeover. The situation depicted in the short story Soaba brings a similar scene from Ngugi's novel $A$ Grain of Wheat, where the detainees (the native villagers) are grouped and sent to camps under colonial administration. They have experienced the most inhuman torture under colonial administration. In addition, in Temsula Ao's depiction of the Indian administration we find a parallel of that brutality. The villages, which harboured the underground rebels/militants or showed sympathy to them were the target of the Indian army:

"... whole villages would be dislodged from their ancestral sites and herbed into new ones, making it more convenient for the security forces to guard them day and night... It was the most humiliating insult that was inflicted on the Naga psyche by forcibly uprooting them from the soil of their origin and being and confining them in an alien environment, denying them access to their fields, restricting them from their routine activities and most importantly, demonstrating to them that the 'freedom they enjoyed could so easily be robbed at gunpoint by the invading army" " [15. P. 11].

The writer strongly advocates the Naga cause which informs the readers across the world about the atrocities meted out against Naga people. The stories fully centre round the lives of Naga people and their exploitation, and the incidents are narrated from the point of view of a Naga, which is only a partial picture. If Temsula Ao sees and analyses it as an insider, Anjum Hasan sees it as a forced 'outsider'. In spite living in Meghalaya for generations, the non-tribal is still designated as an outsider or as the Khasi people prefer to call them "Dkhar". It is because the land, which gives the tribal their identity, is only a land of opportunity for the outsiders, the El Dorado, for the first generation of immigrants. They do not associate themselves with the land as the second generation does. Land, which plays a pivotal role in forming the identity of the tribal, plays the same role in the formation of identity of the second generation non-tribal. The 'dkhar' has long been uprooted from their ancestral land and they have come to live in the land of the Khasi people; and since the former can never claim their affinity with the land, it naturally alienates them from the politics of nationalism fomented by the tribal. These outsiders will continue to be outsiders even if they 
live there for several generations. Although the socio-political reality is different for these two groups, the emotional attachment to the land is not much different. A Khasi may not suffer from identity crisis in his/her homeland; however, a nontribal constantly suffers from this problem as evident in the three principal characters in Lunatic in My Head. They have to go through acceptance and rejection, love and hatred, friendship and animosity of the tribal people. The plot of Lunatic in My Head is situated in Meghalaya, a tribal state in Indian hinterland where the conflict is not between the rebels and the government forces but between the 'outsider' and 'insider'. The conflict is between the Khasis and the 'Dkhars'. This is why Dr. Moondy, a doctor by profession, tells his son, Aman:

"Shillong has no future. In my time, things were different. One could make a life here. There were opportunities. People were open minded... sab khatam ho gaya. That time has gone. Now people, boys, you know, boys half of your height, barge into people's shops, into offices, and demand money" [5. P. 65].

This entire region, which is seen as a land of opportunity (a capitalist expansion), brought the immigrants as traders and professionals. But Aman felt unlike his father:

"This town, he thought, longingly. Concordella lives somewhere in this town. He loved Shillong the way he loved her - shyly, hesitantly, not sure if he was entitled to" [5. P. 65].

His love for Concordella is conflated with his love for Shillong, the place where he was born. And like Concordella, the place is unattainable, so somehow he has to get out of Shillong. However, this feeling of leaving Shillong for good has been indoctrinated by the older generation into the new generation but Aman is caught in this dilemma for some time until he actually leaves Shillong. Whereas for the first generation Shillong was the land of opportunity, for the second generation Shillong is their homeland. This made the relation between land and the people intense and unaffected. Much like Aman, Firdaus Ansari too imagines Shillong as her homeland. To foster a sense of belonging she fancied the idea of marriage between tribal and non-tribal.

She privately liked the idea that Mr. Nivedita, as she thought of him, was in love with a tribal girl. It made her happy to think that connections were still being established between people from opposite sides of that invisible, yet palpable, line that divide people in Shillong [5. P. 16].

She privately rebels against the idea of marrying a devout Muslim's son to appease her grandfather. On the contrary, she not only eats pork, but also deliberately falls in love with Ibomcha, a Manipuri youth. She is enchanted by Shillong: "The beauty of it, she would think as she walked, the beauty of it. Firdaus found that she longed for Shillong even as she lived there, even though she had lived there all her life" [5. P. 101]. This desire to be accepted as a Khasi comes from the rejection and humiliation that one has no face for not being a Khasi. Sophie, like Aman, has numerous encounters with Khasis that belittles her dignity for not being Khasi. Whereas, Aman was physically abused, Sophie underwent the psychological humiliation of being ignored. Precisely, they are unwanted. The feeling of Sophie Das, as narrated by Anjum Hasan, comes from a sense of belongingness, from the desire to be accepted. Anjum Hasan shares with us her experience of being a non-Khasi in Shillong through Sophie Das. The stigma of being a non- 
Khasi, the other/outsider, despite of being born there haunts Sophie Das that she starts living in her fictitious world. This sense of belongingness and the fear of rootlessness at the same time run throughout the novel and it becomes the perennial issue with all the principal characters - Firdaus Ansari, Sophie Das and Aman Moondy. Whereas this conflict exists within the characters, it also becomes visible in the external conflict: the constant animosity between the tribal and nontribal. The attacks on the non-tribal people are frequently mentioned in the novel, the gap between these two groups seem to be growing despite the efforts of the local people like Ribor and David Rockwell. There will always be people like Ribor's brother, Max, who will keep telling, "You Fucking Dkhar... Go home Dkhar" [5. P. 240].

Whereas the setting of these two works is the Northeast region, Mamang Dai's novel goes beyond the regional boundaries and is set in Delhi, where the tribal people from Northeast becomes the 'outsider' within the same national space. The stigma of rejection and alienation becomes evident in the various encounters between the people from northeast and mainland India. Adna, the narrator is a city-bred girl for whom real life is only in Delhi. Her close friend Amine, originally from Jammu, although brought up in Shillong because of her father's association with ONGC in Assam, does not seem to encounter the difficulty that Adna faces because of her tribal features. Adna, who hails from Itanagar, ventures as a female entrepreneur by establishing 'Four Seasons', a small hotel-apartment bequeathed to her by an aunt. Far from the hills of Arunachal, she is captivated by the posh life of the city dwellers and struggles to establish herself in the hotel business with the help of her relatives and Amine. Adna is at once aware of the differences when she says, "Oh, the North-East is a different country altogether" [16. P. 13], and she also longs for an acceptance that she is equally an Indian. She says:

"There were so many of us in the city now, from Mizoram, Meghalaya, Nagaland, from Arunachal, Assam, Manipur and Sikkim, and we mingled with others from every small town and settlement of the country" [16. P. 13].

The exodus is thus a reverse trend from the hills to the plains, which in some way points to us the success of the government to create a sense of panIndian nationalism. However, the difficulty lies at the grass root level, and most often, the people from the northeast have the bitterest experience in such endeavours of assimilation. Jia, a cousin of Adna narrates one such experience in her encounter with a Delhite, when the lady screams at her, "Hey you! Jao! Jao! Go back to your own... DESH!" [16. P. 52], to which Jia retorts:

"How dare you say such a thing? Do you think I'm Chinese, huh? I am Indian. Do you know where I come from? Do you know where that is you idiot woman? Moreover, I bet you are not even from Delhi. You must be from some lousy backwaters! Jao! Jao! Hah! In addition, even if I was Chinese you have no right to say such a thing to anyone! It's people like you who create hatred, you know that? You scum! And then she spat into the cab!" [16. P. 52].

Mamang Dai narrates numerous instances of such unpleasant experiences to highlight the fact that the problem of acceptance and rejection are not limited to one place, but is seen as a strategy to maintain the homogeneity of a community at one place. She also narrates how the Indian government has carried on develop- 
mental works in northeastern India, which resulted in the creation of new settlements in the hill areas by non-tribal people who came as employees to work in those projects [17]. Mareb's father is one such man who "was one among the breed of gypsy men of mixed antecedents who travelled far and wide in search of adventure and fortune, and who now toured the frontier speaking the language of the communities and marrying into the tribes" [16. P. 36].

The restructuring of the backward tracts and change in governmental policies concerning developmental works have occurred in a sequence which has made a very deep impact in the lives of the people living in this region. Unlike Temsula Ao, Mamang Dai believes in pan-Indian nationalism despite cultural disparities between tribal and non-tribal people. Whereas, the existence of customary law in hill region, which allows polygamy to a man, might sound shocking in Delhi, the idea of buying bottled water sounds equally shocking to Jia when she visits Delhi. Therefore, the writer attempts to strike a balance by purportedly underscoring tolerance and togetherness.

\section{Conclusion}

The problem posed by Temsula Ao, Mamang Dai and Anjum Hasan continues persisting in the face of Capitalist exploitation and cultural rejection both in the context of Northeast India and Mainland India. The pre-modern society, which had the capacity to assimilate people whoever migrated from whatever places, was a more receptive society. However, the modern society after the beginning of colonisation not only made the cartographic boarders rigid but also created invisible cultural borders through its practice of exploitation and cultural subjugation. The identity crisis faced by the various characters discussed in the fictional world above informs the reader about the insider/outsider politics because in a modern world with limited resources there is a stiff competition in all the important sectors of the society. Be it possession of land rights or a job vacancy, the limited availability has created a closed circuit which tries to create a false consciousness of belongingness based on ethnicity. This problem can only be overcome by adequate representation of people living in the frontier states in mainland India, and knowledge about the cultures of frontier states. On the other hand, the indigenous people living in northeast India should also be willing to accept the non-tribal people who have lived here for centuries. To conclude an inclusive social culture is the requirement of the time.

\section{References}

[1] McDuie-Ra, D. (2017). Solidarity, visibility and vulnerability 'northeast' as a racial category in India. In Y. Saikia \& A.R. Baishya (Eds.), Northeast India A Place of Relations (pp. 27-44). Delhi, Cambridge University Press.

[2] Gogoi, D. (2016). Unheeded hinterland. New York, Routledge.

[3] Baruah, S. (2005). Durable disorder: Understanding the politics of Northeast India. New Delhi, OUP.

[4] Bhaumik, S. (2009). Troubled periphery: Crisis of India's north east. New Delhi, Sage.

[5] Hasan, A. (2007). Lunatic in my head. New Delhi, Zubaan-Penguin.

[6] Baruah, S. (1999). India against itself: Assam and the politics of nationality. New Delhi, OUP. 
[7] Baruah, S. (2020). In the name of the nation: India and its northeast. Stanford, Stanford University Press.

[8] Guha, A. (2014). Planter Raj to Swaraj. 3rd ed. New Delhi, Tulika Books.

[9] Misra, T. (1980). Assam: A colonial hinterland. Economic \& Political Weekly (pp. 1357-1364).

[10] Chatterjee, P. (1999). Nationalist thought and the colonial world: A derivative discourse? The Partha Chatterjee Omnibus. New Delhi, Oxford University Press.

[11] Dev, R. (2006). Narrative claims and identity impasse: The experiences of the nowhere people. Ethno-Narratives: Identity and Experience in North East India (pp. 79-91). Delhi, Akanshah Publishing House.

[12] Misra, U. (2014). India's north east: Identity movements, state and civil society. New Delhi, Oxford University Press.

[13] Sarma, A. (2016, February). Migrancy and memory in Siddhartha Deb's novel "The Point of Return". Trans-Humanities Journal, 9(1), 129-150. DOI: 10.1353/trh.2016.0006.

[14] Biswas, D. (2020). 'The impasse of Khilanjiya identity in Assam'. Corvinus Journal of Sociology and Social Policy, 11(1). http://dx.doi.org/10.14267/CJSSP.2020.1.10

[15] Ao, T. (2006). These hills called home. New Delhi, Penguin.

[16] Dai, M. (2009). Stupid Cupid. New Delhi, Penguin.

[17] Mackenzie, A. (2012). History of the relations of the government with the hill tribes of the north-east frontier of Bengal. Cambridge University Press.

\section{Bio notes:}

Debajyoti Biswas, Assistant Professor of the Department of English at the Bodoland University. E-mail: deb61594@gmail.com.

Rupanjit Das, research scholar in the Department of English at Bodoland University, Assistant Professor in the Department of History, GLC College, Gauhati University. E-mail: dasrupanjit@gmail.com.

\section{Сведения об авторах:}

Бисвас Дебаджьоти, доцент кафедры английского языка Бодоландского университета. E-mail: deb61594@gmail.com.

Дас Рупанджит, научный сотрудник кафедры английского языка Бодоландского университет, доцент кафедры истории колледжа GLC Университета Гаухати. E-mail: dasrupanjit@gmail.com. 